\title{
Alpha-Santalol, a Component of Sandalwood Oil Inhibits Migration of Breast Cancer Cells by Targeting the $\beta$-catenin Pathway
}

\author{
AJAY BOMMAREDDY ${ }^{1}$, KACEY KNAPP ${ }^{1}$, ABIGAIL NEMETH ${ }^{1}$, JAMES STEIGERWALT $^{1}$, \\ TERRA LANDIS ${ }^{1}$, ADAM L. VANWERT ${ }^{1}$, HARSHA P. GORIJAVOLU ${ }^{2}$ and CHANDRADHAR DWIVEDI ${ }^{3}$ \\ ${ }^{1}$ Department of Pharmaceutical Sciences, Nesbitt School of Pharmacy, \\ Wilkes University, Wilkes-Barre, PA, U.S.A.; \\ ${ }^{2}$ Aurobindo Pharma, Dayton, NJ, U.S.A.; \\ ${ }^{3}$ Department of Pharmaceutical Sciences, College of Pharmacy, \\ South Dakota State University, Brookings, SD, U.S.A.
}

\begin{abstract}
Background/Aim: Alpha-santalol, a terpenoid found in sandalwood oil has been shown to inhibit breast cancer cell growth in vitro by inducing apoptosis, but the mechanisms underlying the growth inhibitory effects of alpha-santalol are not fully understood. In this study, we demonstrate that $\alpha$-santalol treatment targets Wnt/ $\beta$-catenin pathway to inhibit migration of cultured breast cancer cells. Materials and Methods: Migration assays, immunoblotting and immunofluorescence were used to examine the mechanism of action of a-santalol in breast cancer cells. Results: Exposure of MDA-MB 231 and MCF-7 cells to $\alpha$ santalol resulted in a significant reduction in their migratory potential and wound healing ability. In addition, $\alpha$-santalol affected the localization of $\beta$-catenin from cytosol to nucleus in MDA-MB 231 cells. Conclusion: Alpha-santalol inhibited migration of breast cancer cells may be mediated, in part, by targeting Wnt// $\beta$-catenin pathway. $\beta$-catenin represents an important target of $\alpha$-santalol's response for future preclinical studies.
\end{abstract}

Despite significant strides in disease treatment and prevention, breast cancer still remains one of the most commonly diagnosed cancers and the second leading cause of cancer-related deaths in women worldwide (1). It is estimated that 1 in every 8 women will develop breast cancer

Correspondence to: Ajay Bommareddy, Ph.D., Department of Pharmaceutical Sciences, Nesbitt School of Pharmacy, Wilkes University, 84 W. South Street, Wilkes-Barre, Pennsylvania 18766, U.S.A. Tel: +1 5704084220, Fax: +1 5704084299, e-mail: ajay.bommareddy@wilkes.edu

Key Words: Alpha-santalol, $\beta$-catenin, breast cancer. in their lifetime and that there will be 266,120 new cases of breast cancer and 40,920 deaths due to breast cancer in 2018 in the United States (1). Approximately $50 \%$ of women with breast cancer will develop a metastatic disease. Once the disease develops in to a metastatic form, traditional treatment options including radiation and chemotherapy become less effective. Cell migration is one of the key factors that drives the progression of metastatic cancers, which is a major cause of cancer related deaths (2).

One of the major signaling pathways associated with cancer development and metastasis is the $\mathrm{Wnt} / \beta$-catenin pathway. Aberrant activation of the Wnt pathway has been shown to be involved in the development of various human cancers and studies also identified that Wnt signaling may be frequently de-regulated in breast cancer and that $\beta$-catenin is frequently found stabilized and nuclear in breast tumors (3). This pathway is involved in various cellular processes including cell proliferation, migration and invasion. When not activated, the downstream effectors of the pathway including axin, adenomatous polyposis coli (APC), casein kinase-1 (CK1) and glycogen synthase kinase-3 $\beta$ (GSK-3 $\beta$ ) form a complex called destruction complex (DC) which phosphorylates $\beta$-catenin and subsequently cause its degradation. Upon activation of Wnt signaling, $\beta$-catenin is hypophosphorylated and separated from DC to become stabilized in the cytoplasm. Subsequently, $\beta$-catenin translocate to the nucleus and regulates expression of various genes including MYC and cyclin D1 $(4,5)$.

A continuous increase in cancer incidence and failure of conventional treatment options against advanced breast cancer warrants development of novel agents to treat and prevent this malignancy. Hence development of agents that target cellular pathways involved in metastasis is highly desirable. Alphasantalol, a terpenoid extracted from sandalwood oil has been 
shown to have antitumor properties against a wide range of cancers including breast cancer (6-10). Previous studies from our laboratory have shown that $\alpha$-santalol induces apoptosis in cultured breast cancer cells by targeting intrinsic and extrinsic pathways and also through suppression of survivin $(9,10)$. In this study, we investigated the mechanistic details pertinent to the growth suppressive effects of $\alpha$-santalol, specifically focusing on the $\mathrm{Wnt} / \beta$-catenin pathway. It is demonstrated, for the first time, that $\alpha$-santalol inhibits the migration of breast cancer cells and inhibits localization of $\beta$ catenin from the cytosol to the nucleus.

\section{Materials and Methods}

Reagents. $\alpha$-Santalol used in the study was isolated as described by us previously (9). Cell-culture reagents, including RPMI 1640 medium, MEM medium, FBS, and penicillin/streptomycin antibiotic mixture were purchased from Invitrogen-Life Technologies (Carlsbad, CA, USA). Six well Boyden chamber inserts were purchased from Fisher scientific (Pittsburgh, PA, USA). All the antibodies used in the study were purchased from Cell Signaling (Danvers, MA, USA). Eosin and hematoxylin were purchased from Sigma (St. Louis, MO, USA). Other chemicals used in the study were purchased in their highest purity available.

Cell lines. Cell lines of MDA-MB 231 and MCF-7, which were previously authenticated by Research Animal Diagnostic Laboratory (University of Missouri, Columbia, MO, USA) to test for interspecies contamination and alleles for short tandem repeats identifiable in the ATCC database, were a generous gift from Dr. Shivendra V. Singh (University of Pittsburgh Cancer Institute, Pittsburgh, PA, USA). MDA-MB 231 cells were cultured in RPMI Nutrient Mixture supplemented with $10 \%$ (v/v) FBS and $1 \%$ penicillin/streptomycin antibiotic mixture. The MCF-7 cells were maintained in MEM medium supplemented with sodium pyruvate $(1 \mathrm{mM} / \mathrm{l})$, non-essential amino acids $(1 \mathrm{mM} / \mathrm{l}), 10 \%$ (v/v) FBS and $1 \%$ penicillin/streptomycin antibiotic mixtures. Each cell line was maintained in an atmosphere of $95 \%$ air and $5 \% \mathrm{CO}_{2}$ at $37^{\circ} \mathrm{C}$. A stock solution of $\alpha$-santalol was prepared in DMSO and an equal volume of DMSO (final concentration $<0.5 \%$ ) was added to the controls.

Wound healing migration assay. The wound healing assay was performed by plating cells in culture dishes. In brief, a monolayer of MDA-MB 231 or MCF-7 cells were wounded by scratching with sterile pipette tips and washed with PBS. Fresh medium containing different concentrations of $\alpha$-santalol or DMSO was added to the scratched monolayers for 0,24 and $48 \mathrm{~h}$. Images were taken using an inverted Nikon Bright field microscope at 100x magnification after the respective treatment period. Images were taken from three randomly selected fields and the assay was repeated twice independently.

Boyden chamber migration assay. The Boyden chamber migration assay was conducted using Transwell chambers (Costar; Cat. \# 3422). Briefly $0.5 \mathrm{ml}$ of MDA-MB-231 cell suspension containing $1 \times 10^{5}$ cells in complete medium was mixed with either DMSO or desired concentrations of $\alpha$-santalol and the suspension was added to the upper chamber. The lower compartment chamber was filled with $1.5 \mathrm{ml}$ of complete medium containing the same concentrations of $\alpha$-santalol or DMSO and left to incubate for $24 \mathrm{~h}$. After the incubation time, the non-migratory cells that remained on the upper side of the insert membranes were removed by using a cotton swab. The cells that migrated on to the lower side of the membrane insert were fixed and stained with eosin and hematoxylin. Images of the stained cells were captured using Nikon bright field microscope at the magnification of 100x. Three randomly selected images were scored and verified by two individuals. The degree of the inhibition of migration was determined by comparing images of DMSO to images of the cells treated with $\alpha$-santalol $(20 \mu \mathrm{M}, 40 \mu \mathrm{M})$. The percentage of invasive cells was expressed using untreated control cells at $100 \%$.

Immunoblotting. Cells treated with the given concentrations of $\alpha$-santalol or DMSO (control) for specific time periods were processed for immunoblotting. Lysate proteins were resolved by SDS-PAGE and transferred onto (PVDF) membrane and immunoblotting was performed as described by us previously (10). After blocking with blocking buffer (LI-COR, Lincoln, NE, USA), mixed with $0.1 \%$ Tween-20, the membrane was incubated with primary antibodies overnight at $4{ }^{\circ} \mathrm{C}$. Following incubation with appropriate secondary antibody, the immunoreactive bands were visualized using LI-COR-Odyssey infra-red scanner (LI-COR). The blots were re-probed with anti-actin antibody to correct for differences in protein loading.

Immunofluorescence assay. Cells were placed on sterile coverslips in 12-well plates and grown by overnight incubation. The next day, cells were treated with DMSO or $\alpha$-santalol for $24 \mathrm{~h}$. After the treatment period, the cells were rinsed with PBS and fixed with $4 \%$ formaldehyde in PBS. Cells were then incubated in blocking and permeabilization solution $(10 \%$ FCS +0.1 Triton $\times 100$ or $0.1 \%$ Tween 100) for $1 \mathrm{~h}$ followed by primary antibody incubation in the blocking solution overnight. After three washes with PBS, cells were incubated with secondary antibody for $1 \mathrm{~h}$. Cells were rinsed with PBS and the coverslips were mounted on glass slides using mounting media. The cells were visualized under a Nikon Bright field/fluorescence microscope at a magnification of $1000 \times$ for $\beta$-catenin localization.

Statistical analysis. Each experiment was carried out at least twice with triplicate measurements for quantitative comparisons. Statistical significance of difference in measured variables between control and treated groups was determined by one-way ANOVA followed by Bonferroni's multiple comparison test. Differences were considered significant at $p<0.05$.

\section{Results}

$\alpha$-santalol treatment inhibited MDA-MB-231 cells wound healing and migration potential. Effect of $\alpha$-santalol on the wound healing ability of breast cancer cells in vitro was examined initially using a wound healing migration assay. As shown in Figure 1, treatment of MDA-MB 231 cells with $\alpha$-santalol significantly decreased the ability of the cells to cover up the area created by scratching the monolayer in a dose-dependent manner. Similar to the effect observed in MDA-MB 231 cells, $\alpha$-santalol also decreased the wound 
A

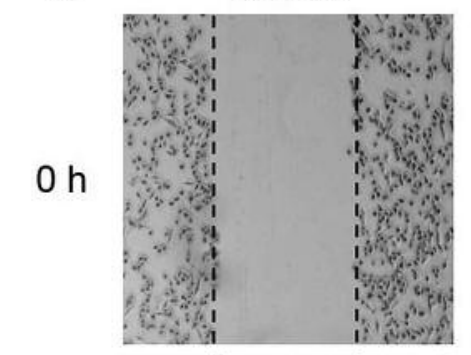

$24 \mathrm{~h}$

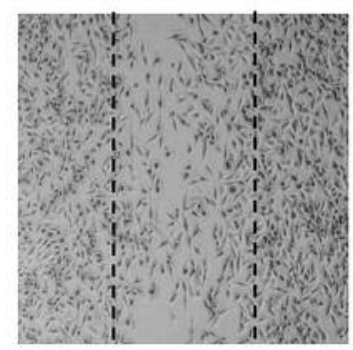

$20 \mu \mathrm{M} \alpha$-santalol
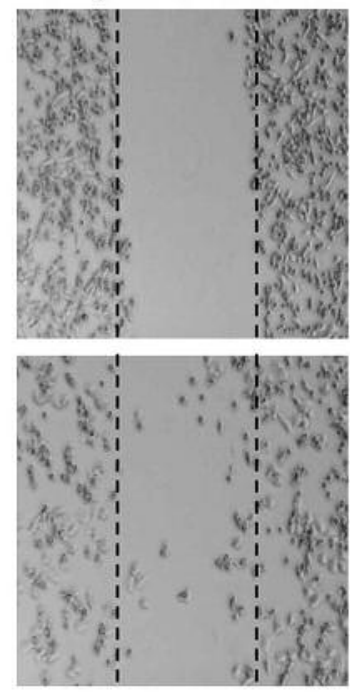

$40 \mu \mathrm{M} \alpha$-santalol
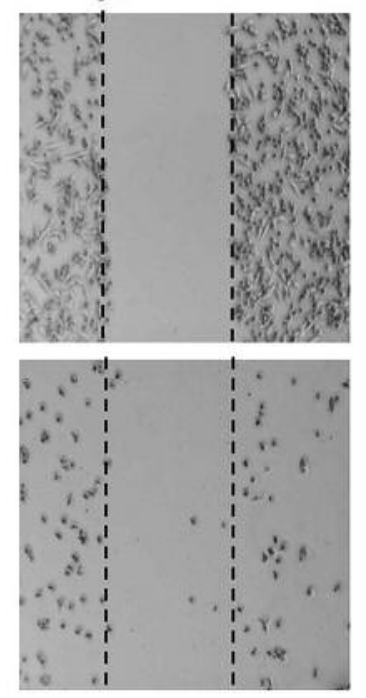

B

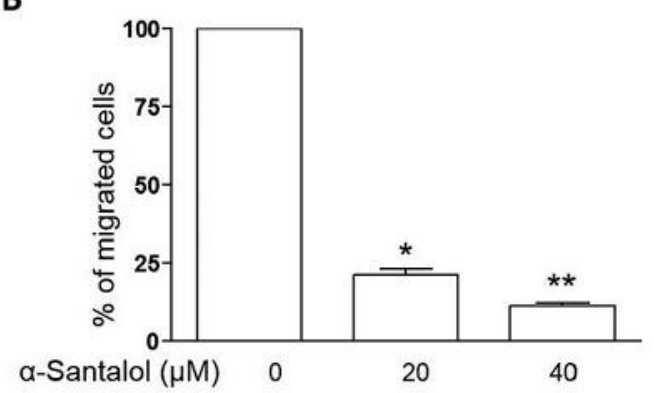

Figure 1. $\alpha$-Santalol treatment affected the wound healing ability of cultured MDA-MB 231 cells. A: Representative images taken at 0,24 h after subjecting the monolayer of cells to in vitro wound healing assay and treatment with $\alpha$-santalol and DMSO. B: Quantitation of filled area composed by cells that migrated after $24 \mathrm{~h}$, represented by percentage of DMSO-treated control cells. Columns, mean ( $n=3)$; bars, SE. Significantly different $\left({ }^{*} p<0.001\right)$ compared to control by one-way ANOVA Bonferroni multiple comparison test.

healing ability of MCF-7 cells (data not shown). Because $\alpha$ santalol inhibited the wound healing properties of MDA-MB 231 cells, we reasoned that it might also influence the migratory potential of the cells. Subsequently, we proceeded to explore the effect of $\alpha$-santalol on the invasive potential using a trans well migration assay. Figure 2A depicts hematoxylin and eosin-stained images of migrating MDAMB 231 cells after $24 \mathrm{~h}$ treatment with DMSO (control) and 20, $40 \mu \mathrm{M} \alpha$-santalol. As can be seen in Figure $2 \mathrm{~B}$, migration of MDA-MB 231 cells was inhibited significantly in a concentration-dependent manner. For example, compared to control the average number of migratory cells was lowered by $\sim 48 \%(p<0.001)$ and $\sim 73 \% \quad(p<0.001)$, respectively, in the presence of 20 and $40 \mu \mathrm{M} \alpha$-santalol (Figure 2B). These results showed that alpha-santalol significantly reduced not only the wound healing properties but also the migratory potential of MDA-MB 231 cells. $\alpha$-santalol treatment blocked the translocation of $\beta$-catenin to nucleus. Because $\mathrm{Wnt} / \beta$-catenin signaling plays a crucial role in cell migration, we proceeded to determine whether $\alpha$ santalol-mediated suppression of migratory potential and wound healing properties are regulated through this pathway. For this purpose, $\beta$-catenin localization was analyzed using immunofluorescence microscopy. As can be seen in Figure 3, $\beta$-catenin localization in the cytosol is predominantly intense in $\alpha$-santalol-treated (Figure 3E) compared to control-treated cells (Figure 3B) after a $24 \mathrm{~h}$ treatment period. Moreover, translocation of $\beta$-catenin to the nucleus is clearly evident in the control-treated (Figure 3C) vs. alpha-santalol-treated cells (Figure $3 \mathrm{~F}$ ), suggesting that aalpha-santalol may regulate the pathway to inhibit the migration of MDA-MB 231 cells.

Effect of $\alpha$-santalol on levels of $\beta$-catenin in breast cancer cells. Next, the expression of phoshpho $\beta$-catenin and total 

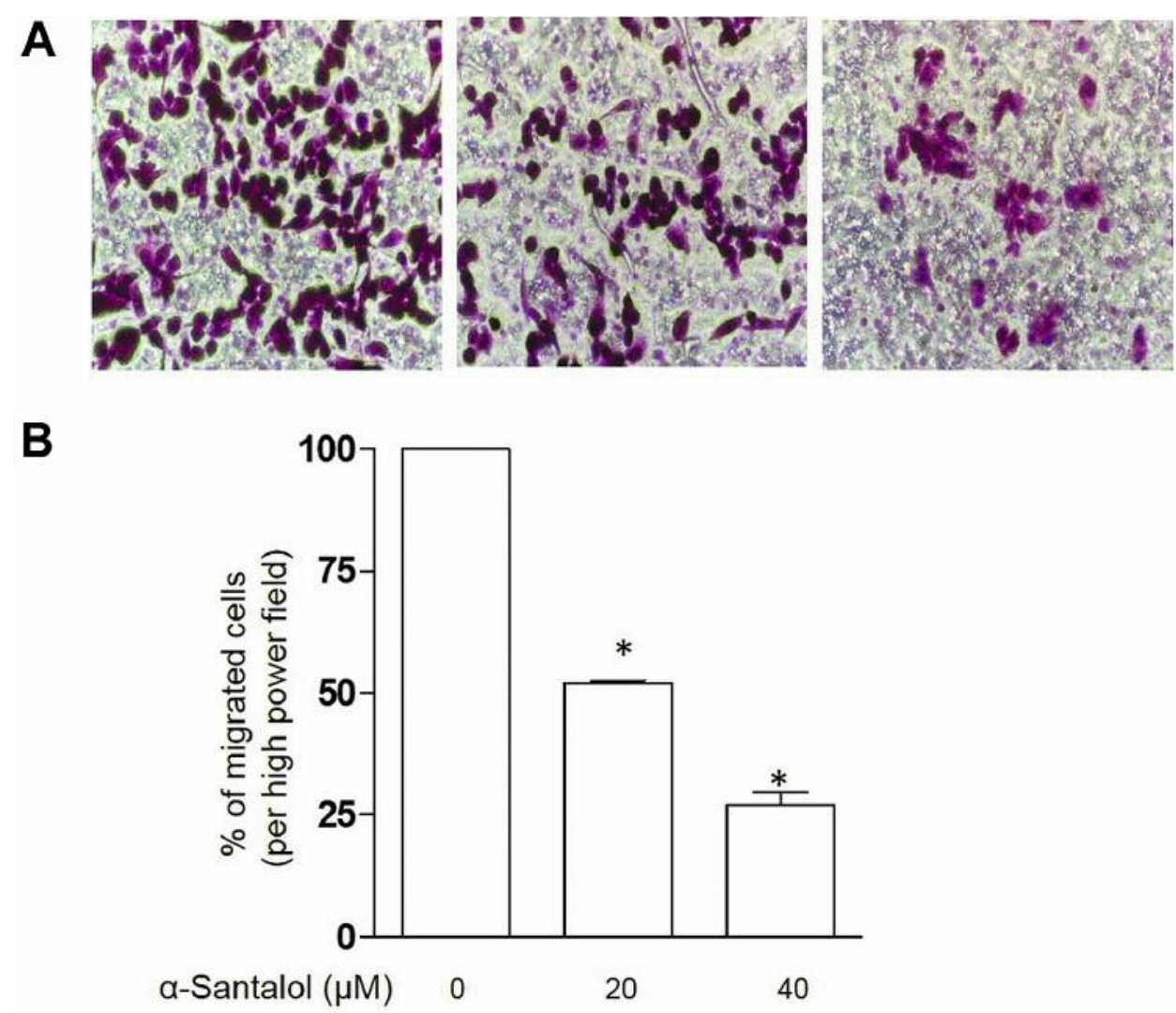

Figure 2. $\alpha$-Santalol treatment inhibited migration of cultured MDA-MB-231 cells. A: Representative images depicting the effect of $\alpha$-santalol treatment on MDA-MB-231 cell migration. B: Quantitation of migrating cells per high-power field represented by percentage of DMSO-treated control cells. Columns, mean ( $n=3)$; bars, SE. Significantly different $\left({ }^{*} p<0.001\right)$ compared to control by one-way ANOVA Bonferroni multiple comparison test.

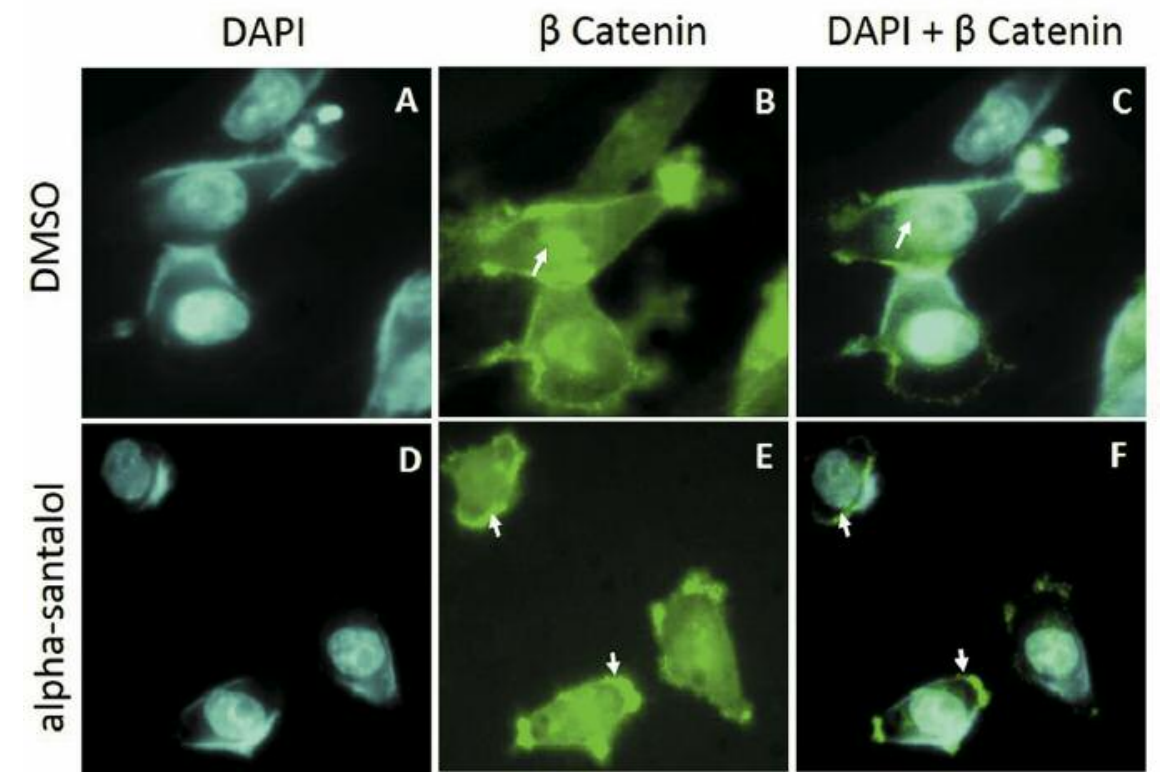

Figure 3. $\alpha$-Santalol treatment affected the translocation of $\beta$-catenin in to nucleus in cultured MDA-MB-231 cells. Representative images depicting the effect of DMSO and $40 \mu \mathrm{M}$ alpha-santalol treatment on localization of $\beta$-catenin. 
A MDA-MB 231 cells

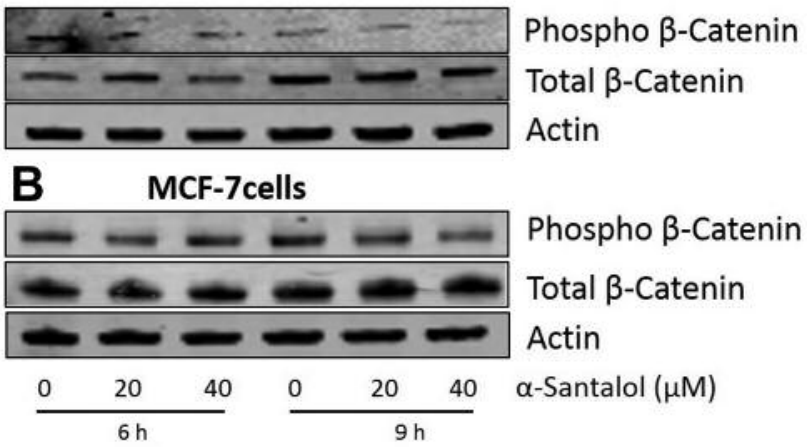

Figure 4. Effect of $\alpha$-santalol on $\beta$-catenin protein expression. Detection of phospho and total $\beta$-catenin protein by western blotting of cell lysates from MDA-MB 231 cells $(A)$ and MCF-7 cells $(B)$ treated with the indicated concentrations of $\alpha$-santalol for 6 and $9 h$. Actin was used as a loading control.

$\beta$-catenin were compared in complete cell lysates to determine if $\alpha$-santalol affected the levels. As shown in Figure 4A, $\alpha$-santalol decreased the expression of phoshpho $\beta$-catenin levels when compared to control-treated MDAMB 231 cells. Similarly, the expression levels of phospho $\beta$-catenin in MCF-7 cells, as shown in Figure 4B, were also decreased in $\alpha$-santalol treated cells when compared to the control cells.

\section{Discussion}

Previous work from our laboratory pointed the involvement of cell-cycle arrest and subsequent apoptotic cell death mediated through intrinsic and extrinsic pathways in cellular responses to $\alpha$-santalol, a natural sesquiterpene from sandalwood oil $(8,9)$ but the mechanisms underlying the breast tumor cell growth inhibitory properties of $\alpha$-santalol was unclear. Our earlier studies also identified that $\alpha$ santalol-mediated antitumor effects in breast cancer cells may be regulated in part, through suppression of survivin (10). In the same study, we also showed that survivin down regulation is not mediated through PI3K-Akt pathway (10). Most recently, a study focusing on transdermal/transpapillary delivery of $\alpha$-santalol significantly reduced tumor incidence and multiplicity where significantly reduced in a rat chemical carcinogenesis model (11). The present study indicated that $\alpha$-santalol's inhibition of the migratory potential of breast cancer cells may be mediated through suppression of the $\beta$ catenin pathway. This conclusion is supported by the following experimental data: (a) the migration potential of $\alpha$-santalol-treated cells was significantly lower than DMSOtreated control cells; (b) the $\alpha$-santalol treatment blocks the translocation of $\beta$-catenin to nucleus in MDA-MB 231 cells; (c) downregulation of phoshpho $\beta$-catenin levels in cells treated by $\alpha$-santalol. Even though further studies are needed to determine the precise mechanism by which $\alpha$-santalol inhibits the migration and promotes cell-cycle arrest, it is possible that $\alpha$-santalol stabilizes $\beta$-catenin levels in the cytoplasm, blocks its translocation to the nucleus and subsequently down-regulates the expression of genes associated with cellular migration and cell-cycle progression.

The Wnt/ $\beta$-catenin pathway that comprises of several proteins has been shown to be vital for various functions including stem cell regeneration and development of organs $(12,13)$. Abnormal activation of Wnt signaling pathway plays a crucial role in the development of various types of human cancers and tumor recurrence (12). It is also well established that deregulation of Wnt signaling is frequently observed in the development of breast cancer where $\beta$-catenin is nuclear in its localization. $\beta$-catenin serves as an oncogene where once it is nuclear and can bind to T Cell factor (TCF) or lymphoid enhancer family (LEF) members to activate its downstream effector genes such as cyclin D1 and c-myc, associates with cell cycle progression and development of tumors $(14,15)$. In addition, deregulation of Wnt signaling is also positively associated with the expression of anti-apoptotic genes such as survivin through $\beta$-catenin/TCF-mediated transcription (16, 17). Studies also revealed that Akt-dependent regulation of $\beta$ catenin plays a major role in tumor invasion and development where it was shown that phosphorylation of $\beta$-catenin by Akt increases its transcriptional activity and promotes tumor cell invasion (5). We have previously demonstrated that $\alpha$-santalol mediated antitumor effects in breast cancer cells may be regulated, in part, through suppression of survivin, facilitating cell cycle arrest and promoting apoptosis $(9,10)$. Also, in a mouse model of UVB-induced skin tumor development, we showed that $\alpha$-santalol significantly reduced expression of key regulators of cell cycle including cyclin D1 and its dependent kinase cdk4 (18). Because survivin and cyclin D1 are crucial downstream effectors of $\beta$-catenin signaling, it is logical to speculate that $\alpha$-santalol may be targeting $\beta$-catenin to promote cell cycle arrest and induce apoptosis.

In conclusion, the present study demonstrated that $\alpha$-santalol mediating antitumor effects in breast cancer cells may be regulated, in part, by targeting $\beta$-catenin to further facilitate cell-cycle arrest and induction of apoptosis. Further studies are warranted to determine the exact role of $\alpha$-santalol mediated cell growth suppression of breast cancer cells.

\section{Acknowledgements}

The Authors would like to acknowledge the "provost research \& scholarship" grant awarded to AB by Wilkes University, and thank Dr. Paul S. Adams and the mentoring task force at Wilkes University for supporting undergraduate students. 


\section{References}

1 Siegel RL, Miller KD and Jemal A: Cancer statistics. CA Cancer J Clin 68(1): 7-30, 2018.

2 Ham SL, Nasrollahi S, Shah KN, Soltisz A, Paruchuri S, Yun YH, Luker GD, Bishayee A and Tavana H: Phytochemicals potently inhibit migration of metastatic breast cancer cells. Integr Biol (Camb) 7(7): 792-800, 2015.

3 Schlange T, Matsuda Y, Lienhard S, Huber A and Hynes NE: Autocrine WNT signaling contributes to breast cancer cell proliferation via the canonical WNT pathway and EGFR transactivation. Breast Cancer Res 9(5): R63, 2007.

$4 \mathrm{Hu} \mathrm{Y,} \mathrm{Yu} \mathrm{K,} \mathrm{Wang} \mathrm{G,} \mathrm{Zhang} \mathrm{D,} \mathrm{Shi} \mathrm{C,} \mathrm{Ding} \mathrm{Y,} \mathrm{Hong} \mathrm{D,} \mathrm{Zhang}$ D, He H, Sun L, Zheng JN, Sun S and Qian F: Lanatoside C inhibits cell proliferation and induces apoptosis through attenuating $\mathrm{Wnt} / \beta$-catenin/c-Myc signaling pathway in human gastric cancer cell. Biochem Pharmacol 150: 280-292, 2018.

5 Fang D, Hawke D, Zheng Y, Xia Y, Meisenhelder J, Nika H, Mills GB, Kobayashi R, Hunter T and Lu Z: Phosphorylation of beta-catenin by AKT promotes beta-catenin transcriptional activity. J Biol Chem 282(15): 11221-11229, 2007.

6 Bommareddy A, Brozena S, Steigerwalt J, Landis T, Hughes S, Mabry E, Knopp A, VanWert AL and Dwivedi C: Medicinal properties of alpha-santalol, a constituent of sandalwood oil. Nat Prod Res 1-17, 2017. doi: 10.1080/14786419.2017.1399387. [Epub ahead of print]

7 Bommareddy A, Rule B, VanWert AL, Santha S and Dwivedi C: $\alpha$-santalol, a derivative of sandalwood oil, induces apoptosis in human prostate cancer cells by causing caspase- 3 activation. Phytomedicine 19: 804-811, 2012.

8 Zhang X, Chen W, Guillermo R, Chandrasekher G, Kaushik RS, Young A, Fahmy $\mathrm{H}$ and Dwivedi C: Alpha-santalol, a chemopreventive agent against skin cancer, causes $\mathrm{G}_{2} / \mathrm{M}$ cell cycle arrest in both p53-mutated human epidermoid carcinoma A431 cells and p53 wild-type human melanoma UACC-62 cells. BMC Res Notes 3: 220, 2010.

9 Santha S, Bommareddy A, Rule B, Guillermo R, Kaushik RS, Young A and Dwivedi C: Antineoplastic effects of $\alpha$-santalol on estrogen receptor-negative breast cancer cells through cell cycle arrest at $\mathrm{G}_{2} / \mathrm{M}$ phase and induction of apoptosis. PLOS ONE 8: $1-12,2013$.
10 Bommareddy A, Crisamore K, Fillman S, Brozena S, Steigerwalt, J, Vanwert AL and Dwivedi C: Survivin down regulation by $\alpha-$ santalol is not mediated through PI3K-AKT pathway in human breast cancer cells. Anticancer Research 35(10): 5353-5357, 2015.

11 Dave K, Alsharif FM, Islam S, Dwivedi C and Perumal O: Chemoprevention of breast cancer by transdermal delivery of $\alpha$ santalol through breast skin and mammary papilla (nipple). Pharm Res 34(9): 1897-1907, 2017.

12 Krishnamurthy $\mathrm{N}$ and Kurzrock R: Targeting the Wnt/betacatenin pathway in cancer: Update on effectors and inhibitors. Cancer Treat Rev 62: 50-60, 2018.

13 Gammons M and Bienz M: Multiprotein complexes governing Wnt signal transduction. Curr Opin Cell Biol 51: 42-49, 2017.

14 Lin SY, Xia W, Wang JC, Kwong KY, Spohn B, Wen Y, Pestell RG and Hung MC: Beta-catenin, a novel prognostic marker for breast cancer: its roles in cyclin D1 expression and cancer progression. Proc Natl Acad Sci USA 97(8): 4262-4266, 2000.

15 He TC, Sparks AB, Rago C, Hermeking H, Zawel L, da Costa LT, Morin PJ, Vogelstein B and Kinzler KW: Identification of cMYC as a target of the APC pathway. Science 281(5382): 1509$1512,1998$.

16 Guha $\mathrm{M}$ and Altieri DC: Survivin as a global target of intrinsic tumor suppression networks. Cell Cycle 8(17): 2708-2710, 2009.

17 Chang E, Donahue J, Smith A, Hornick J, Rao JN, Wang JY and Battafarano RJ: Loss of p53, rather than beta-catenin overexpression, induces survivin-mediated resistance to apoptosis in an esophageal cancer cell line. J Thorac Cardiovasc Surg 140(1): 225-232, 2010.

18 Santha S and Dwivedi C: $\alpha$-Santalol, a skin cancer chemopreventive agent with potential to target various pathways involved in photocarcinogenesis. Photochem Photobiol 89(4): 919-926, 2013. 